\title{
Taxonomic significance of pollen morphology in Succisa and Succisella
}

\author{
Zoya M. Tsymbalyuk*, Sergei L. Mosyakin \& Lyudmila M. Nitsenko
}

Department of Systematics and Floristics of Vascular Plants, M. G. Kholodny Institute of Botany, National Academy of Sciences of Ukraine, Tereshchenkivska 2, Kyiv 01004, Ukraine; ORCID: ZMT - https://orcid.org/0000-0003-2768-0045, SLM - https://orcid.org/0000-00023570-3190, LMN - https://orcid.org/0000-0003-1945-7409

*corresponding author (e-mail: palynology@ukr.net)

\begin{abstract}
Pollen morphology of representatives of the genera Succisa and Succisella in the flora of Ukraine was studied using light and scanning electron microscopy. Pollen grains in both taxa were tricolpate, prolate, rarely oblate-spheroidal or spheroidal; large-sized. Their outline in polar view was subcircular, rarely trilobate, in equatorial view elliptical or rarely circular. Colpi short, of variable width, margins irregular with distinct, narrow margo, and blunt or acute ends. Exine sculpture was echinate-microechinate. The revealed characteristics of pollen grains are taxonomically significant at the generic and specific levels, and they can be used in pollen analysis. Palynomorphological data are consistent with the results of recent molecular phylogenetic studies. Data on pollen morphology also confirm taxonomic circumscription of Succiseae V. Mayer \& Ehrend. Pollen grains in Succiseae are characterized by a tricolpate aperture type, which was probably ancestral in Dipsacaceae s. str.
\end{abstract}

Key words: pollen grains, morphology, sculpture, diagnostic characters, taxonomy, Ukraine

\section{Introduction}

Earlier, Succisa Haller and Succisella G. Beck were usually placed in the family Dipsacaceae Juss. (Bobrov 1957; Kotov 1961; Takhtajan 1987, 1997, 2009). According to the latest versions of the Angiosperm Phylogeny Group (APG III 2009; APG IV 2016) system, they are included in an extended family Caprifoliaceae s. 1. (also with Diervillaceae Pyck, Morinaceae Raf., Valerianaceae Batsch, etc.). Molecular phylogenetic studies Dipsacaceae in the strict sense, and of some related families, were conducted by several groups of researchers (Donoghue et al. 1992; Caputo \& Cozzolino 1994; Bell et al. 2001; Bremer et al. 2001; Zhang et al. 2003; Caputo et al. 2004; Bell \& Donoghue 2005; Avino et al. 2009; Carlson et al. 2009, etc.). Earlier researchers subdivided Dipsacaceae mainly into three tribes: Knautieae Janchen, Dipsaceae Rchb., and Scabioseae DC. Succisa and Succisella were usually assigned to Scabioseae, together with Scabiosa L. (Bobrov 1957; Kotov 1961, etc.). According to results of molecular phylogenetic studies, Succisa and Succisella are sister taxa in the ITS and combined analyses, and only in cpDNA analyses, Succisella was resolved as a weakly supported sister group to Pseudoscabiosa Devesa (Avino et al. 2009; Carlson et al. 2009; Jacobs et al. 2011; Mayer 2016). According to new morphological and molecular phylogenetic studies, Succisa and Succisella are included in Succiseae V. Mayer \& Ehrend., subfam. Dipsacoideae (Mayer \& Ehrendorfer 2013; Mayer 2016).

The genus Succisa, in its current narrow circumscription, includes three species: two with small relict ranges (S. pinnatifida Longe in the Iberian Peninsula and S. trichotocephala Baksay endemic to W Africa) and one rather widespread species, $S$. pratensis, naturally occurring in Europe, W Siberia, and N Africa (Bobrov 1957; Mabberley 1997; Mayer 2016). The genus Succisella contains five currently accepted species. Three of them (S. carvalhoana (Mariz) Baksay, S. microcephala (Willk.) G. Beck, and S. andreae-molinae Pajarón \& Escudero) are endemic to the Iberian Peninsula (Amich et al. 2004). Succisella petteri (Kerner \& Murb.) G. Beck is endemic to the Dinara Planina (Bosnia and Croatia) and $S$. inflexa (Kluk) G. Beck is distributed in southern and eastern parts of Europe, from Italy to Baltic states in the north and the Caucasus in the south. In other regions, $S$. inflexa is considered to be 
alien and naturalized (Amich et al. 2004; Mabberley 1997; Mayer 2016). Two species, Succisa pratensis and Succisella inflexa, are native members the flora of Ukraine and adjacent countries (Bobrov 1957; Kotov 1961; Mosyakin \& Fedoronchuk 1999).

Pollen grains of Succisa pratensis were earlier described using light microscopy (Erdtman 1952; Vinokurova 1959; Moore \& Webb 1983). The PalDat electronic database contains information on the pollen morphology of S. pratensis under scanning electron microscopy (Halbritter \& Svojtka 2016). Pollen grains of S. pratensis were also studied using both light and scanning electron microscopy (Clarke \& Jones 1981). The morphological peculiarities of pollen grains of Iberian taxa Succisella microcephala, S. andreae-molinae, and S. carvalhoana were also investigated using both light and scanning electron microscopy (Amich et al. 2004).

Our main objective was to perform a more detailed palynomorphological investigation of Ukrainian species Succisa pratensis and Succisella inflexa, to provide assessment of the taxonomic significance of pollen morphology of Succisa and Succisella based on both published and original data, and to explore possibilities of its uses in taxonomy.

\section{Materials and methods}

Pollen grains of Succisa and Succisella were sampled in the National Herbarium of Ukraine (KW - herbarium of the M. G. Kholodny Institute of Botany, National Academy of Sciences of Ukraine, Kyiv, Ukraine). Data on the studied specimens are cited exactly according to the label information, in English translation.

The methods used in the present study are essentially the same as those we used earlier (see Mosyakin \& Tsymbalyuk 2015a, 2015b, 2017). Pollen morphology was studied using both light microscopy and scanning electron microscopy. For light microscopy studies (LM,
Biolar, $\times 700$ ), the pollen was acetolyzed following Erdtman (1952). For size determinations, 20 measurements were taken along the polar and equatorial axes for each species. Permanent preparations of pollen grains of Succisa and Succisella are deposited in the Palynotheca at the National Herbarium of Ukraine (KW). For scanning electron microscopy (SEM, JSM-6060LA), pollen grains were treated with $96 \%$-ethanol, then the samples were sputter-coated with gold and investigated at the Center of Electron Microscopy of the M.G. Kholodny Institute of Botany. The micrographs were minimally edited with Adobe Photoshop 6.0 to enhance images.

Terminology used in descriptions of pollen grains mainly follows the glossary by Punt et al. (2007), with some necessary minor adjustments (Tsymbalyuk et al. $2018,2019)$. Original and published data on quantitative pollen characters representatives of Succiseae are summarized in Table 1.

\section{Results}

\subsection{General description of pollen grains of Succiseae}

Pollen grains in monads, radially symmetrical, isopolar, tricolpate, prolate, rarely spheroidal or oblatespheroidal, in polar view subcircular, rarely trilobate, in equatorial view elliptical, rarely circular. Polar axis $\mathrm{P}=66.5-98.4 \mu \mathrm{m}$, equatorial axis $\mathrm{E}=65.2-98.4 \mu \mathrm{m}$. Colpi short, of variable width, 0.7-5.3 $\mu \mathrm{m}$ wide, $26.6-37.2 \mu \mathrm{m}$ long, margin irregular with distinct, narrow margo, 0.7$2.0 \mu \mathrm{m}$ wide, with blunt or acute ends, colpus membrane smooth or granulate, often ruptured during acetolysis. Exine 6.6-10.6 $\mu \mathrm{m}$ thick, unevenly thickened, rarely on apocolpia thicker. Columellae distinct, short, occasionally longer in apocolpium. Exine sculpture echinatemicroechinate. Echinae conical with straight sides and acute apex, 0.9-1.5 $\mu \mathrm{m}$ high, 1.0-1.3 $\mu \mathrm{m}$ wide at base. Microechinae small, more numerous than echinae, 0.2$0.3 \mu \mathrm{m}$ high, 0.3-0.4 $\mu \mathrm{m}$ wide at base. Exine surface

Table 1. Morphometric comparison of pollen grains

\begin{tabular}{|c|c|c|c|c|c|c|}
\hline Taxon & $\begin{array}{l}\text { Polar axis, } \mathrm{P} \\
\quad(\mu \mathrm{m})\end{array}$ & $\begin{array}{l}\text { Equatorial axis, } \\
\mathrm{E}(\mu \mathrm{m})\end{array}$ & $\begin{array}{c}\text { Colpi } \\
\text { length }(\mu \mathrm{m})\end{array}$ & $\begin{array}{l}\text { Colpi width } \\
\quad(\mu \mathrm{m})\end{array}$ & $\begin{array}{l}\text { Margo } \\
(\mu \mathrm{m})\end{array}$ & $\begin{array}{l}\text { Exine } \\
(\mu \mathrm{m})\end{array}$ \\
\hline $\begin{array}{l}\text { Succisa pratensis } \\
\text { (Clarke \& Jones 1981) }\end{array}$ & $68(77)-84(95)$ & $69(75)-79(98)$ & $26-32$ & $3-7$ & $1.5-2.5$ & $8-11$ \\
\hline $\begin{array}{l}\text { Succisa pratensis } \\
\text { (original data) }\end{array}$ & $73.1-98.4$ & $66.5-98.4$ & $27.9-37.2$ & $2.0-5.3$ & $1.3-2.0$ & $6.6-10.6$ \\
\hline $\begin{array}{l}\text { Succisella inflexa } \\
\text { (original data) }\end{array}$ & $66.5-79.8$ & $65.2-79.8$ & $26.6-29.3$ & $0.7-4.0$ & $0.7-1.6$ & $6.6-9.3$ \\
\hline $\begin{array}{l}\text { Succisella carvalhoana } \\
\text { (Amich et al. 2004) }\end{array}$ & $63.60 \pm 3.52$ & $65.71 \pm 2.71$ & ld & ld & ld & ld \\
\hline $\begin{array}{l}\text { Succisella microcephala } \\
\text { (Amich et al. 2004) }\end{array}$ & $64.83 \pm 2.98$ & $66.93 \pm 2.65$ & ld & ld & ld & ld \\
\hline $\begin{array}{l}\text { Succisella andreae-molinae } \\
\text { (Amich et al. 2004) }\end{array}$ & $64.11 \pm 3.10$ & $66.27 \pm 2.89$ & ld & ld & ld & ld \\
\hline
\end{tabular}

Explanation: 1d - lack of data 
between echinae and microechinae rugulate or rugulate-perforate. Colpus membrane with irregular granules and short echinae.

\subsection{Descriptions of pollen grains}

\section{Genus Succisa Haller}

Succisa pratensis Moench. (Fig. 1a-c; Fig. 2a-d)

L M. Pollen grains tricolpate, prolate, rarely spheroidal, often with slightly undulating margin, in polar view subcircular, rarely trilobate, in equatorial view elliptical, rarely circular. $\mathrm{P}=73.1-98.4 \mu \mathrm{m}, \mathrm{E}=66.5-98.4 \mu \mathrm{m}$. Colpi short, 2.0-5.3 $\mu \mathrm{m}$ wide, 27.9-37.2 $\mu \mathrm{m}$ long, margin irregular with distinct, narrow margo, 1.3-2.0 $\mu \mathrm{m}$ wide, with blunt or acute ends, colpus membrane smooth or granulate, often ruptured during acetolysis. Exine 6.6$10.6 \mu \mathrm{m}$ thick, unevenly thickened, rarely on apocolpia thicker. Tectum 3-4 times thinner than infratectum. Columellae distinct, short, of variable thickness, often fused into groups, branched above, arranged more or less regularly, rarely on apocolpia longer. Endexine unevenly thickened. Echinae indistinct on the surface, distinct on the edges, sparsely distributed. Columellae distinct, circular, elongated or angular, at the base in LO analysis, densely distributed.

SEM. Exine sculpture echinate-microechinate. Echinae conical with straight sides and acute apex, 1.3$1.5 \mu \mathrm{m}$ high, 1.2-1.3 $\mu \mathrm{m}$ wide at base. Microechinae small, more numerous than echinae, $0.2-0.3 \mu \mathrm{m}$ high, 0.3-0.4 $\mu \mathrm{m}$ wide at base. Exine surface between echinae and microechinae rugulate-perforate. Colpus membrane with irregular granules and short echinae.

Specimens investigated: 1. Ukraine, Zhytomyr Region. Volodarsk-Volynsky District. St. Turchanka, pasture in the birch-alder forest. 30.07.1949. A. Zapyatova (KW). 2. Ukraine, near Vinnitsa [Vinnytsya], wet meadow north of the railway in the direction of
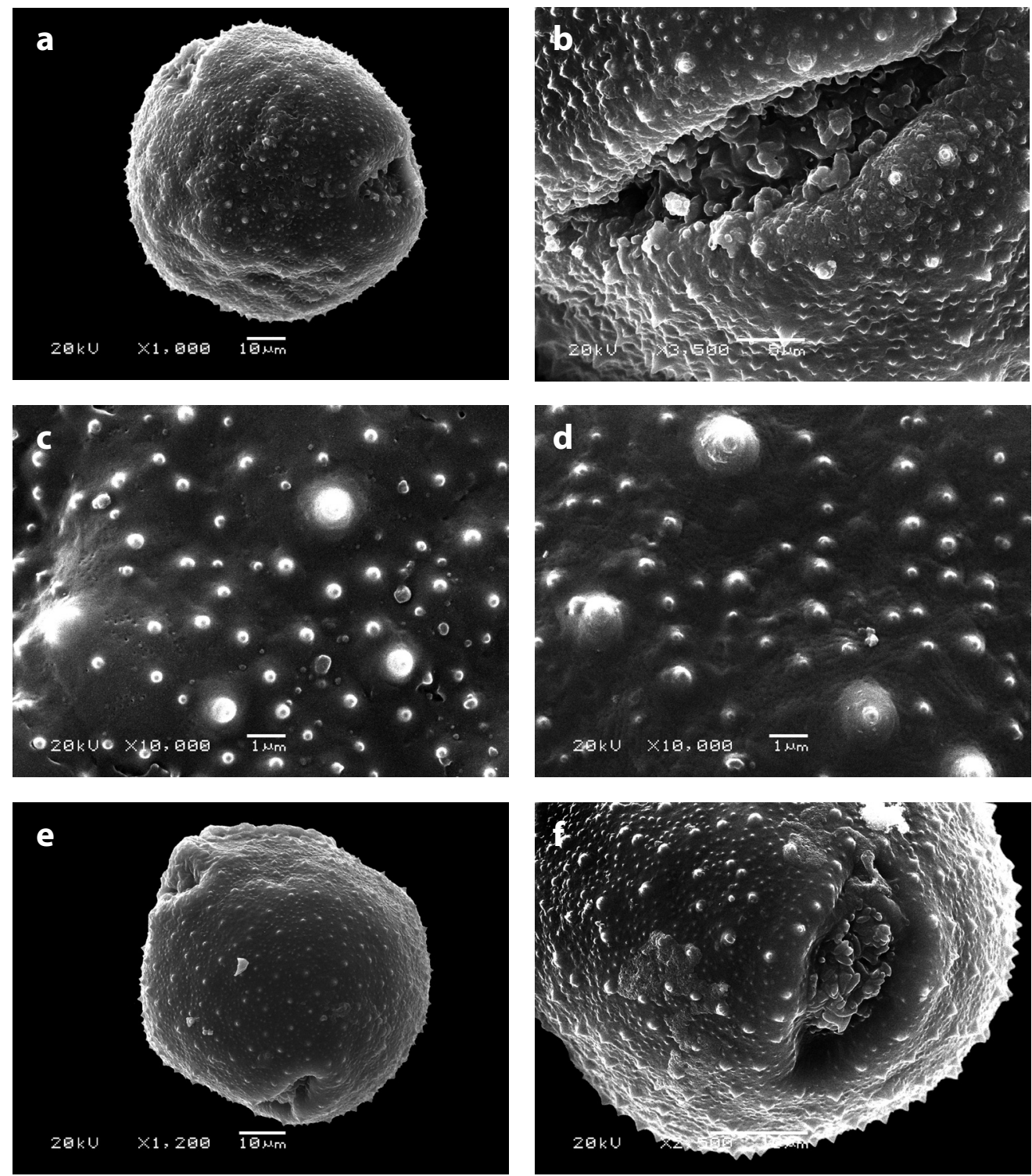

Fig. 1. Pollen grains of Succisa pratensis and Succisella inflexa (SEM) Explanations: a-c - S. pratensis, d-f-S. inflexa, a, e-polar view, b, f-colpi membranes with irregular granules and short echinae, c, d-exine sculpture 
Sosenke (Kalinovka). 24.VIII 1927. K.S. Yankovsky (KW). 3. Ukraine, Chernihiv Region, Lyubech District, Lyubech village, floodplain of the Dnipro [Dnieper] River. 28.VII 1952. D. Afanasyev (KW).

Genus Succisella G. Beck Succisella inflexa (Kluk) G. Beck

(Fig. 1d-f; Fig. 2e-h)

L M . Pollen grains tricolpate, prolate, rarely oblatespheroidal or spheroidal, in polar view subcircular, rarely trilobate, in equatorial view elliptical, rarely circular. $\mathrm{P}=66.5-79.8 \mu \mathrm{m}, \mathrm{E}=65.2-79.8 \mu \mathrm{m}$. Colpi short, 0.7-4.0 $\mu \mathrm{m}$ wide, 26.6-29.3 $\mu \mathrm{m}$ long, margin irregular with distinct, narrow margo, 0.7-1.6 $\mu \mathrm{m}$ wide, with acute or sometimes blunt ends, colpus membrane smooth and granulate, often ruptured during acetolysis. Exine 6.6-9.3 $\mu \mathrm{m}$ thick, unevenly thickened. Tectum 4 times thinner than infratectum. Columellae distinct, short, arranged more or less regularly. Endexine unevenly thickened. Echinae indistinct on the surface and at the edges, very sparsely distributed. Columellae distinct, circular, elongated and angular at the base in LO analysis, densely distributed.

SEM. Exine sculpture echinate-microechinate. Echinae conical with straight sides and acute apex, 0.9$1.1 \mu \mathrm{m}$ high, $1.0-1.2 \mu \mathrm{m}$ wide at base. Microechinae small, more numerous than echinae, $0.2 \mu \mathrm{m}$ high, $0.3 \mu \mathrm{m}$ wide at base. Exine surface between echinae and microechinae rugulate. Colpus membrane with irregular granules and short echinae.
Specimens investigated: 1. Ukraine, Volyn' Region, Kovel District, v.[village] Ugli, floodplain of the Stohod [Stokhid] River, peat meadows. 3. VIII 2007. T.L. Andriyenko. 083618 (KW). 2. Ukraine, Lviv Region, Kamenka-Buz'ka District, northwestern outskirts of Tishitsa village, right bank of the Western Bug River, wet meadow. 20.07.1999. O.T. Kuzyarin. 056940 (KW). 3. Belarus, Kamenyuki village, Kamenetsk District, Brest Region. July 26, 1972. O. Dubovik (KW).

\section{Discussion}

In general, our data are in good agreement with the results of previous studies (Clarke \& Jones 1981; Amich et al. 2004). In particular, Amich et al. (2004) provided the following information about pollen grains of Succisella: "The pollen of the Iberian Peninsula species of Succisella (...) is tricolpate (...). No differences were seen between the studied taxa. (...) In all cases, the pollen is oblate-spheroid, almost spheroid, (Figs 13-15) with a weakly striated exine (Figs 19-21), covered in small, sparse spines, the largest of which are $0.8-1 \mathrm{~mm}$ in $S$. microcephala and $S$. andreae-molinae, and the smallest 0.2-0.3 $\mathrm{mm}$ in S. carvalhoana (Figs 16-18). These palynological characteristics reveal the primitive nature of the genus within the Dipsacaceae" (Amich et al. 2004, p. 355).

Pollen grains of Succisella inflexa are similar to those of the Iberian Succisella in their pollen type, size,
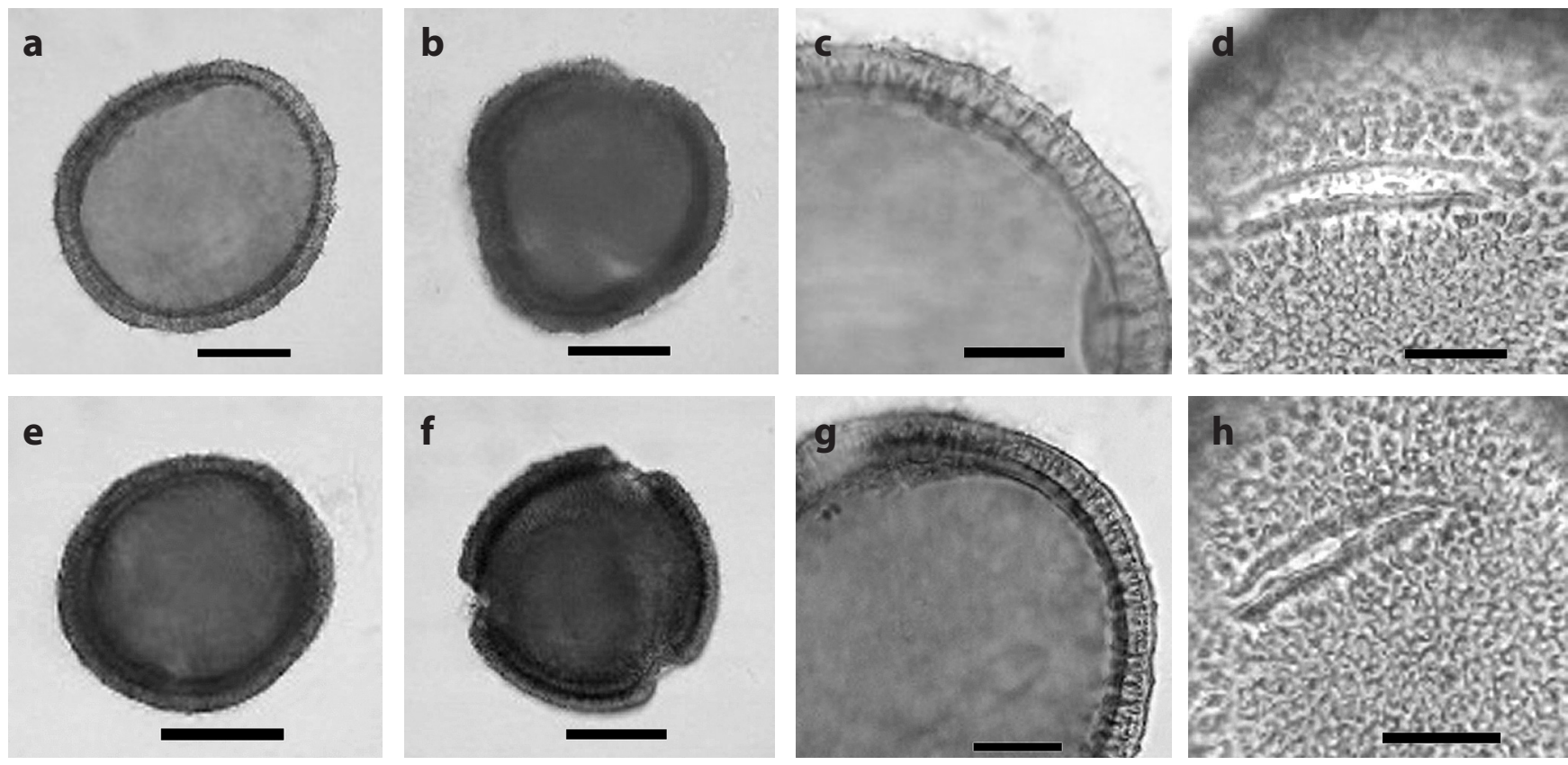

Fig. 2. Pollen grains of Succisa pratensis and Succisella inflexa (LM) Explanations: a-d - S. pratensis, e-h - S. inflexa, a, e - equatorial view $(\times 400), \mathrm{b}, \mathrm{f}-$ polar view $(\times 400), \mathrm{c}, \mathrm{g}-$ exine $(\times 700), \mathrm{d}, \mathrm{h}-$ colpi $(\times 700)$; scale bars: $\mathrm{a}-\mathrm{h}-10 \mu \mathrm{m}$ 
and exine sculpture. Unfortunately, the illustrations and characters reported by Amich et al. (2004) are insufficient for a more detailed comparative analysis.

Analysis of our original palynomorphological data and literature records demonstrated that pollen grains of Succisa and Succisella representatives are characterized by the tricolpate type of apertures with echinatemicroechinate sculpture (see also Clarke \& Jones 1981; Amich et al. 2004; Mayer \& Ehrendorfer 2013, and compare to original data reported here); however, they differ in their size, colpi structure, and exine structure and sculpture. Pollen grains of Succisa are larger in their size, with wider and longer colpi, wider margo, and thicker exine, as compared to pollen of Succisella. The exine sculpture in both taxa is echinate-microechinate, but in pollen grains of Succisa echinae are larger than those in Succisella (Clarke \& Jones 1981; Amich et al. 2004, and original data). The species-specific features mentioned above are mainly visible under a light microscope (see LM descriptions above) and, therefore, LM can be used in performing pollen analysis.

Thus, available palynomorphological data are well consistent with molecular phylogenetic evidence (Avino et al. 2009; Carlson et al. 2009). Data on pollen morphology also confirm the taxonomic circumscription of Succiseae as outlined by Mayer (2016). Pollen grains in Succiseae are characterized by a tricolpate aperture type (see details above). In contrast, representatives of Knautia L., Dipsacus L., and Cephalaria Schrad. ex Roem. \& Schult. usually have a triporate aperture type (Clarke \& Jones 1981; Tsymbalyuk et al. 2018, 2019, and references therein). Palynological evidence, thus, supports the phylogenetic hypothesis (Caputo et al. 2004; Carlson et al. 2009) that the 'Knautieae' group is more closely related to Dipsacus and Cephalaria than to Succisa and Succisella. The palynomorphological characters in Succiseae can be probably viewed as ancestral, or, at least, close to ancestral, or primary for those registered in other members of Dipsacaceae sensu stricto.

Acknowledgements. The authors express their gratitude to Natalia M. Shyian, Head Curator of the National Herbarium of Ukraine (KW; M.G. Kholodny Institute of Botany, National Academy of Sciences of Ukraine), for her cooperation and assistance in extracting pollen samples from herbarium specimens at KW. Kind help and cooperation of Dmytro O. Klymchuk, Head of the Center of Electron Microscopy, and Vitaliy I. Sapsay, SEM operator (M. G. Kholodny Institute of Botany, National Academy of Sciences of Ukraine), are greatly appreciated. We also thank Veronika Mayer (Division of Structural and Functional Botany, University of Vienna, Vienna, Austria) for providing several important references. The authors are grateful to anonymous reviewers and the editorial staff of the journal for their valuable comments and suggestions.

\section{Author Contributions}

Research concept and design: Z. M. Tsymbalyuk, S. L. Mosyakin

Acquisition and/or assembly of data: Z. M. Tsymbalyuk, L. M. Nitsenko

Data analysis and interpretation: Z. M. Tsymbalyuk Drafting the article: Z. M. Tsymbalyuk, L. M. Nitsenko Critical revision: S. L. Mosyakin

Final approval: S. L. Mosyakin, Z. M. Tsymbalyuk

\section{References}

APG III (Angiosperm Phylogeny Group III). 2009. An update of the Angiosperm Phylogeny Group classification for the orders and families of flowering plants: APG III. Bot. J. Linn. Soc. 161: 105-121.

APG IV (Angiosperm Phylogeny Group IV). 2016. An update of the Angiosperm Phylogeny Group classification for the orders and families of flowering plants: APG IV. Bot. J. Linn. Soc. 181: 1-20.

Amich F., Devesa J. A. \& Bernardos S. 2004. Taxonomic revision of the genus Succisella (Dipsacaceae) in the Iberian Peninsula. Bot. J. Linn. Soc. 144: 351-364.

Avino M., Tortoriello G. \& Caputo P. 2009. A phylogenetic analysis of Dipsacaceae based on four DNA regions. Pl. Syst. Evol. 279: 69-86.
Bell C. D. \& Donoghue M. J. 2005. Dating the diversification of Dipsacales: comparing models, genes, and evolutionary implications. Am. J. Bot. 92: 284-314.

Bell C. D., Edwards E. J., Kim S.-T. \& Donoghue M. J. 2001. Dipsacales phylogeny based on chloroplast DNA sequences. Harvard Pap. Bot. 6(2): 481-499.

Bobrov E. G. 1957. Dipsacaceae Lindl. In: B. K. Shyshkin \& E. G. Bobrov (eds.). Flora of the USSR [Flora SSSR], vol. 24, pp. 10-91. Izdatelstvo AN SSSR, Moscow-Leningrad.

Bremer K., Backlund A., Sennblad B., Swenson U., Andreasen K., Huertson M., Lundberg J., Backlund M. \& Bremer B. 2001. A phylogenetic analysis of $100+$ genera and $50+$ families of euasterids based 
on morphological and molecular data with notes on possible higher level morphological synapomorphies. Pl. Syst. Evol. 229: 137-169.

Caputo P. \& Cozzolino S. 1994. A cladistic analysis of Dipsacaceae (Dipsacales). Pl. Syst. Evol. 189: 41-61.

Caputo P., Cozzolino S. \& Moretti A. 2004. Molecular phylogenetics of Dipsacaceae reveals parallel trends in seed dispersal syndromes. P1. Syst. Evol. 246: 163-175.

Carlson S. E., Mayer V. \& Donoghue M. J. 2009. Phylogenetic relationships, taxonomy, and morphological evolution in Dipsacaceae (Dipsacales) inferred by DNA sequence data. Taxon 58(4): 1075-1091.

Clarke G. \& Jones M. R. 1981. The Northwest European pollen flora. Dipsacaceae. Rev. Palaeobot. Palynolog. 33: 1-25. [Reprinted In: W. Punt \& G. C. S. Clarke (eds.). The Northwest European pollen flora, vol. 3, parts 21-28, pp. 21-25. Elsevier Sci. Publ. Company, Amsterdam, etc.].

Donoghue M. J., Olmstead R. G., Smith J. F. \& Palmer J. D. 1992. Phylogenetic relationships of Dipsacales based on $r b c \mathrm{~L}$ sequences. Ann. Missouri Bot. Gard. 79: 333-345.

Erdtman G. 1952. Pollen morphology and plant taxonomy. Angiosperms. 539 pp. Almqvist \& Wiksell, Stockholm.

Halbritter H. \& SvojtKa M. 2016. Succisa pratensis. In: PalDat - A palynological database. https:/www. paldat.org/pub/Succisa_pratensis/301807; accessed 2019-01-23

Jacobs B., Geuten K., Pyck N., Huysmans S., Jansen S. \& Smets E. 2011. Unraveling the phylogeny of Heptacodium and Zabelia (Caprifoliaceae): an interdisciplinary approach. Syst. Bot. 36(1): 231-252. DOI: http://www. bioone.org/doi/full/10.1600/036364411X553306

Koтоv M. I. 1961. Dipsacaceae Lindl. In: M. I. Koтov (ed.). Flora of the Ukrainian SSR [Flora URSR], vol. 10, pp. 339-379. Vydavnytstvo AN URSR, Kyiv.

MABBeRLEy D. J. 1997. The plant-book: a portable dictionary of the vascular plants. Edition 2. 858 pp. Cambridge University Press, Cambridge.

Mayer V. 2016. Dipsacaceae (inclusive Triplostegia). In: K. Kubitzki (ed.). The families and genera of vascular plants, vol. 14, pp. 145-163. Springer International Publishing Switzerland. DOI: https:// doi.org/10.1007/978-3-319-28534-4 11

MAYer V. \& Ehrendorfer F. 2013. The phylogenetic position of Pterocephalidium and the new African genus Pterothamnus within an improved classification of Dipsacaceae. Taxon 62: 112-126.

Mosyakin S. L. \& FedoronchuK M. M. 1999. Vascular plants of Ukraine. A nomenclatural checklist. xxiii +345 pp. Kiev.
Mosyakin S. L. \& Tsymbalyuk Z. M. 2015a. Pollen morphology of the southern African tribe Teedieae, an early-branching lineage of crown Scrophulariaceae. Willdenowia 45: 65-75. DOI: https://doi.org/10.3372/ wi.45.45107

Mosyakin S. L. \& Tsymbalyuk Z. M. 2015b. Pollen morphology of the tribes Aptosimeae and Myoporeae supports the phylogenetic pattern in early-branching Scrophulariaceae revealed by molecular studies. Willdenowia 45: 209-222. DOI: https://doi.org/10.3372/ wi. 45.45207

Mosyakin S. L. \& Tsymbalyuk Z. M. 2017. Pollen morphology of the tribe Hemimerideae: possible evidence of ancestral pollen types and parallel evolution in the basalmost clade of Scrophulariaceae s. str. Willdenowia 47: 15-27. DOI: https://doi.org/10.3372/ wi.47.47102

Moore P. D. \& WebB J. A. 1983. An illustrated guide to pollen analysis. 133 pp. Hodder and Stoughton, London, Sydney, Auckland, Toronto.

Punt W., Hoen P. P., Blackmore S., Nilsson S. \& Le Thomas A. 2007. Glossary of pollen and spore terminology. Rev. Palaeobot. Palynol. 143: 1-81. DOI: http://dx.doi. org/10.1016/j.revpalbo.2006.06.008

TAKHTAJAn A. L. 1987. Systema magnoliophytorum [Sistema magnoliofitov]. 439 pp. Nauka, Leningrad.

Takhtajan A. L. 1997. Diversity and classification of flowering plants. $\mathrm{x}+643$ pp. Columbia University Press, New York.

TAKhtAjan A. 2009. Flowering Plants. xlv +871 pp. Springer Verlag. DOI: https://doi.org/10.1007/978-1-40209609-9

Tsymbalyuk Z. M., Bezusko L. G., Mosyakin S. L. \& NitsenKo L. M. 2019. Pollen morphology of species of Dipsacus (Dipsacaceae) in the flora of Ukraine: significance for taxonomy and spore-pollen analysis. Ukr. Bot. J. 76(1): 9-23. DOI: https://doi.org/10.15407/ ukrbotj76.01.009

Tsymbalyuk Z. M., Bezusko L. G. \& Nitsenko L. M. 2018. Pollen morphology of species of the genus Knautia (Dipsacaceae) in Ukraine: an assessment for taxonomy and spore-pollen analysis. Ukr. Bot. J. 75(3): 248-259. DOI:_https://doi.org/10.15407/ ukrbotj75.03.248

Vinokurova L. V. 1959. Palinologicheskie dannye k sistematike semeystv Dipsacaceae i Morinaceae. In: Problemy botaniki, vol. 4, pp. 51-67. Izdatelstvo AN SSSR, Moscow-Leningrad.

Zhang W.-H., Chen Z.-D., Li J.-H., Chen H.-B. \& Tang Y.C. 2003. Phylogeny of the Dipsacales s. 1. based on chloroplast trnL-F and $n d h \mathrm{~F}$ sequences. Mol. Phylog. Evol. 26: 176-189. 